J. Asiat. Soc. Bangladesh, Sci. 45(1): 93-109, June, 2019

\title{
GEOLOGICAL AND GEOPHYSICAL OBSERVATIONS TO DETERMINE THE GAS SEEPAGE SOURCE OF TITAS GAS FIELD REGION, BANGLADESH
}

\author{
SOUROV DATTA BIJOY*, MD. YOUSUF GAZI*, S.M. MAINUL KABIR \\ AND BADRUL IMAM \\ Department of Geology, University of Dhaka, Dhaka-1000, Bangladesh
}

\begin{abstract}
Titas Gas Field, the largest gas field in Bangladesh, has been encountering gas seepages in numerous points at the surface in an area of about $7 \mathrm{sq} . \mathrm{km}$. at the southeastern part of the field since 2006. Gas has been seeping through the water wells, small and large holes in the fields including agricultural lands, in the river and through the cracks in the ground. The present research attempts to point out the source of the gas seepages based on the field studies, wireline $\log$ analyses and other available borehole data. A reconnaissance resistivity survey has been carried out around the high seepages area to detect any evidence of shallow subsurface fault. No fault was detected by resistivity survey in the shallow depth in the seepage area and thus fault as a conduit for the seepage could not be confirmed. Primarily, all wells of Titas Well Location (TWL-C) (Titas-06, 08, 09 and 10) were suspected as possible source wells as the surface distribution of seepages generally clusters around TWL-C. Titas-06 and Titas-08 were taken out of suspect list as the gas seepage distributions do not follow well path and cement bonding against reservoir sands including ' $\mathrm{A}$ ' sand in these two wells are also good. Gas seepages follow the well trajectories of Titas-09 and 10 wells but cement bonding against 'A' gas sand in Titas-09 also discarded the well as a probable source of the gas seepage. Also, the suggestion that Titas well-03 could be a source of gas seep is also ruled out because of the fact that it is located $3 \mathrm{~km}$ away from the seepage area, there is no evidence of any seepage in between the well 3 and the seepage area, and the gas sands are also well protected. The above evidences turned the whole focus onto Titas-10. Gamma ray, resistivity, density, sonic and neutron log signatures recorded initially in the Titas-10 well strongly indicated a major gas sand and has been designated ' $\mathrm{A}_{1}$ ' gas sand. On the basis of various logs including CBL/VDL log it is evident that about 23 meters (3157-3180-meter MD) gas sand at the top which is not protected by cement. It is most likely source of gas seeps in Titas gas field is the gap in the cement protection at the top of A sand in Titas-10 well.
\end{abstract}

Key words: Titas gas field, Gas seepage, Resistivity survey, Wireline log, Cement bond

\section{Introduction}

Natural hydrocarbon seepages are a well-known occurrence throughout the world and historical references to seepage date back to earliest recorded history (Hunt 1979, Link 1952, Tinkle et al. 1973, Kolpack 1977, Fischer and Stevenson 1973, Estes et al. 1985).

\footnotetext{
*Author for correspondence: <geodatta@gmail.com>, <yousuf.geo@du.ac.bd>.
} 
Natural gas seepages often appear in tectonically unstable areas like continental boundaries where gas come out of the ground due to temperature, pressure or concentration gradient through fault-like features (Sibson 1996).

Natural gas seepages had been observed all over the world (Etiope et al. 2009). In Bangladesh, natural gas seepages are observed in many places in the folded belt i.e Sitakund structure, Dakhin Nila structure while oil seepages are observed in Olatong structure, St. Martin's Island etc. In Bangladesh, human-induced natural gas seepages are caused by events like the blowout of drilling exploratory wells, error in drilling and completion of appraisal or production well and so on. Gas seepages due to the blowout of wells are found in Haripur (Sylhet); Magurchara, (Moulvibazar); Chattak, (Sunamganj). Sylhet-1 in 1955 and Sylhet-4 in 1962 have encountered gas at shallow depth while drilled and resulted in a blowout of drilling equipment and since then, gas leaks from fissures in the well site and catch fire on ignition. A similar blowout incident took place in Moulvibazar-1 in 1997 because of inappropriate casing setting against loose Tipam sand and eventually caused gas to spread through the loose sand layer which escaped to the surface at several points. Error in proper casing against loose Tipam sand led to blowing out of Chattak-2 (Tengratila) well in an identical fashion while gas escaped in loose sand and rushed up to the surface at several points (Imam 2013). These seepages are generally short lived although there are cases where seepages continue to show live gas escaping through the surface for a considerable time span. Gas seepages in Titas gas field are the consequence of human-induced error in the well drilling and completion procedures. There has not been any blowout in Titas field wells, but in certain areas, the poor cementation against one of the major reservoir sands has been suggested to be the cause of gas escape and eventual seepages to the surface. As a consequence, gas seepage continues in the area till date.

Titas gas field started to encounter seepage of very significant amount of gas through hundreds of points including fissures and cracks on the ground and river there, scattering over agricultural fields, water bodies and the Titas river. Also, seepages occur with the tube well which suffered continuous and uncontrolled flow of water with gas. The seeping water was hot and tainted with petroleum. Gas also seeps through ground cracks which remain undetected until it comes in contact with fire. Gas is leaking in form of huge bubbles through the riverbed of Titas river at different spots. Gas seepage problems were first identified in November, 2006. Petrobangla made some initial investigations in which it was suggested that the seeping gas is thermogenic and not biogenic shallow gas. The recommendation was made to work over some of the wells especially 8,9 and 10 . It was decided to do workover job in Titas-3, while for some unknown reasons the well was 
killed and abandoned permanently. However, this has apparently failed to stop the seepage and the gas seepage continues to present days even after more than nine years of killing Titas-3.

The objective of this study is to evaluate the surface distribution of the gas seepage of Titas gas field and to find the causes and source of the seepage. The study also correlates the present-day surface trend of gas seepages with subsurface well trajectories of several deviated Titas wells. There have been a few investigations both in national and international standard after the seepages were noticed first. But there is no research work available in the academic sphere on the gas seepage source investigation of Titas gas field. Overall, there is a good database in terms of availability of some wireline logs which include gamma ray $\log$, resistivity $\log$, sonic $\log$, neutron $\log$, density $\log$, cement bonding $\log (\mathrm{CBL} / \mathrm{VDL} \log )$ etc. Among them, CBL/VDL log is very much important as this log was used to identify the poor cement bonding in several Titas wells and examine whether these poor bonding intervals coincide with gas seeping depth in the well. Titas daily production data of well 1-16 from all 'A', 'B' and 'C' gas sands along with wellhead pressure data was also collected which also helped to track noticeable changes in production from targeted wells as well as to monitor if there was distinguishable drop in wellhead pressure which might be evident to argue a well as a defective well. Resistivity data obtained in the seepage affected area was of shallow depth which extended to only 120-meter depth where no trace of shallow fault was found, if data up to 300-meter depth could be imaged by the resistivity survey, there might be a possibility to find out some shallow fault which could be explained as conduit for seeping gas from major reservoir.

Regional geologic settings of the study area: Bangladesh occupies a large part of the Bengal basin which is bounded by the peninsular shield area of Rajmahal hills in the west, the Arakan-Yoma anticlinorium and the Naga-Lushai orogenic belts in the east, the Shillong plateau and the Himalayan foredeep in the north and the Bay of Bengal in the south (Coleman 1969, Evans 1964). The Sylhet trough lies in the north-eastern part of Bangladesh which is the site of seven gas producing and an oil field (Fig. 1) (Banu and Hossain 2000).

The eastern part of the Sylhet trough lies in the frontal deformation zone of the IndoBurman ranges (Alam et al. 2003, Johnson and Alam 1991). North-south trending folds that are uplifted in the Chittagong-Tripura fold belt plunge northward into the Sylhet trough subsurface (Khan et al. 2006). The anticlines are commonly faulted, and many produce gas (Hiller and Elahi 1984, Lietz and Kabir 1982). The Sylhet trough is bounded 
to the north by the Shillong plateau, which is underlain by a basement complex of Archean gneiss and minor greenstone and upper Proterozoic granite (Acharyya et al. 1986). The Surma series of Miocene consisting of Bhuban and Bokabil formations has excellent development in Surma Trough (Johnson and Alam 1991). Structurally, Sylhet trough has formed due to simultaneous interaction of two major tectonic elements, the rising Shillong massif in the north and westward moving Indo-Burman mobile fold belt on Burmese plate (Johnson and Alam 1991).

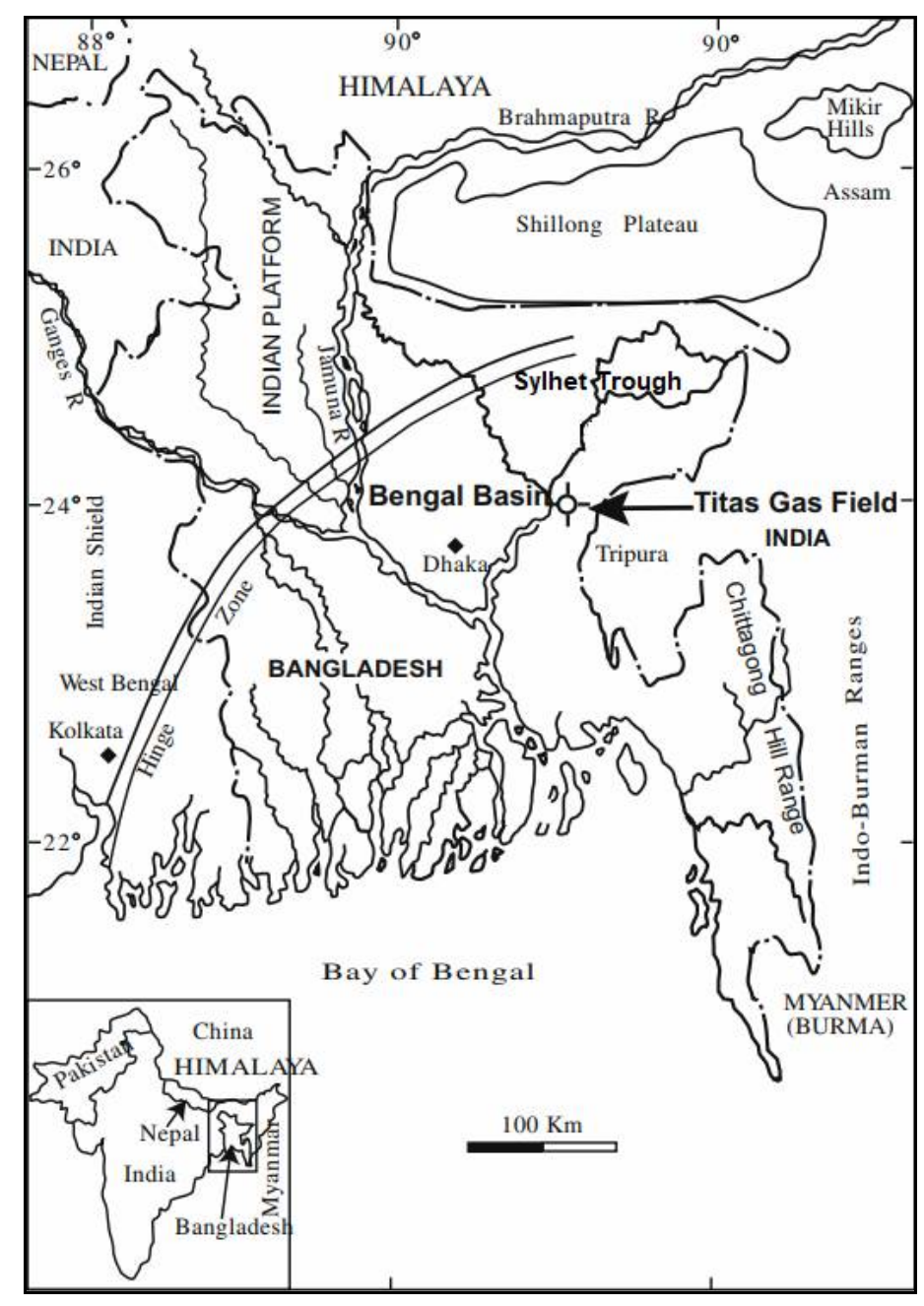

Fig 1. Regional geologic settings and location of Titas gas field (modified after Alam et al. 2003). 


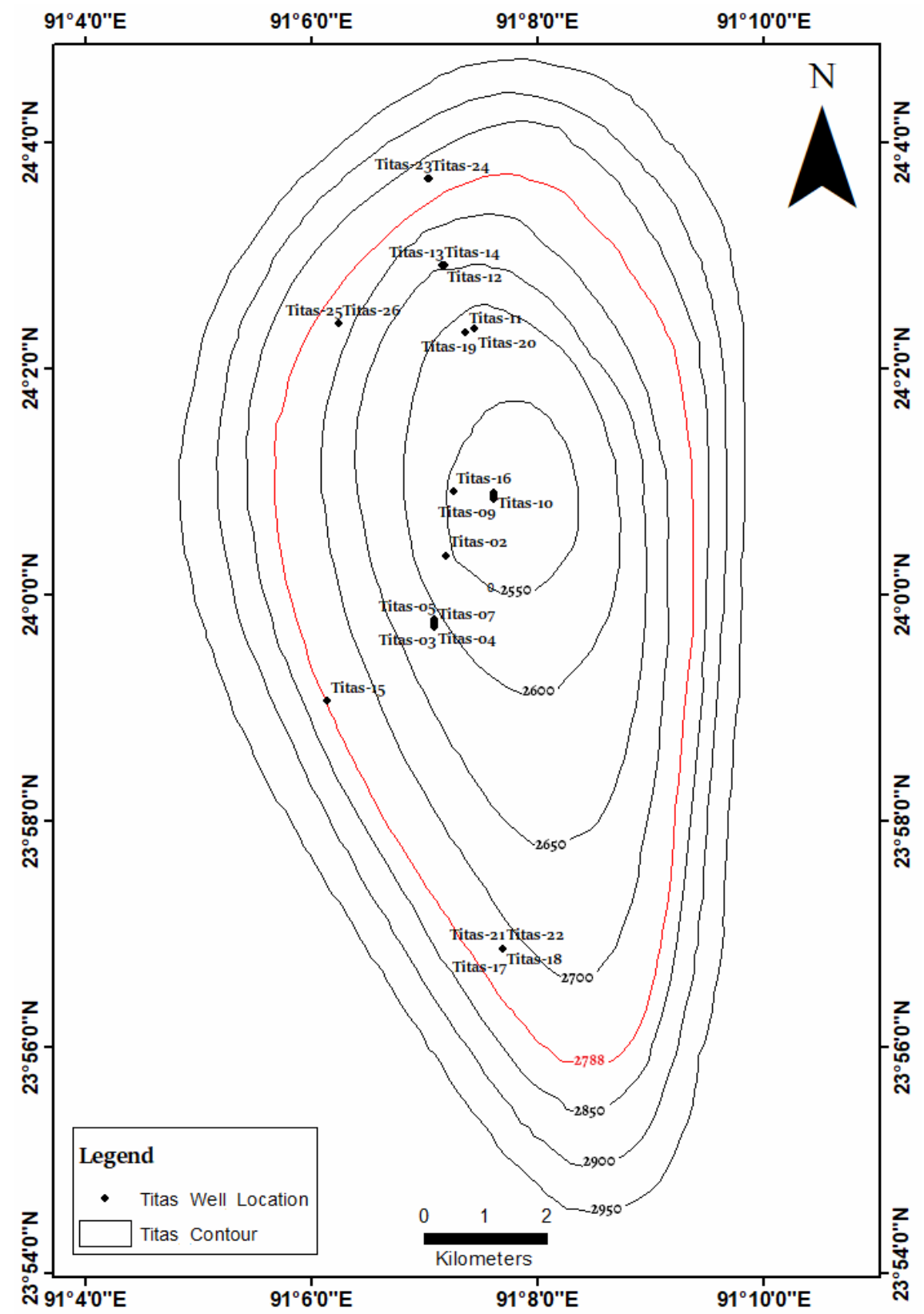

Fig. 2. Titas depth contour map showing N-S trending elongated anticlinal structure. 
Western zone of Sylhet trough consists of relatively simpler geological structures (Fig. 2). The eastern zone is the most prospective gas and oil province of Bangladesh (Biswas 2005).

Titas structure: Titas structure lies on the southern fringe of Sylhet trough and on the western margin of the Chittagong Tripura frontal fold belt (Matin et al. 1984). The structural trend main axis lies along N-S direction, with a broader northern nose and steeper eastern flank (Fig. 3). The eastern flank is steeper than the western flank with the former dipping up to $15^{\circ}$ and the latter dipping not more than $7^{\circ}$. The dip is much gentler in the north-south direction at $3^{\circ}$ and indicates stronger compression and uplift (Imam 2013). This structure has one of the largest closures among the gas fields in this basin, measuring in excess of 16 kilometer by 8 kilometers at the topmost pay sand level. There is no surface expression of this structure as it is covered by the Titas-Meghna flood plain (Imam 2013). The reservoir sands in the area are composed of stacked sands which are divided into three groups 'A', 'B' and ' $C$ ' sands. Group 'A' sands are the most prolific in terms of petroleum generation which are the dominant constituent of the reservoirs in the Titas field. This sand zone consists of sandstone which is light grey to white with a salt and pepper texture, very fine to fine grain and subangular to sub-rounded. The siltstone and shales are found to be interbedded with the sandstone. The sandstones are separated by shales and also have shale bedding within them. These sands constitute the gas reservoir within the area (Farhaduzzaman et al. 2015).

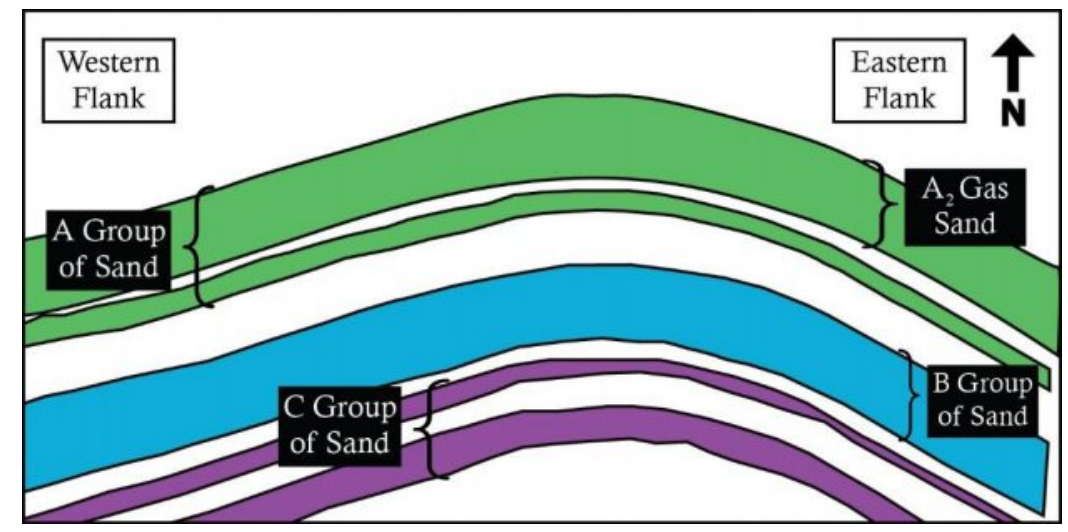

Fig. 3. Schematic diagram of Titas anticlinal structure with steeper eastern flank and gentler western flank. (modified after Miah and Howladar 2014).

Overview of petroleum geology: Gas samples from the seepages collected by BAPEX and BGFCL were analyzed in both BAPEX and BUET laboratory. All the analyses indicated 
that the gas is thermogenic and only source of this type of gas in this area are the gas reservoirs of the gas field, more precisely the 'A' group of sands (Huq 2009). The gas sands of Titas gas field represent a geological set. Five major gas sands occur in the Titas gas fields which are denoted as $\mathrm{A}_{2}, \mathrm{~A}_{3}, \mathrm{~A}_{4}, \mathrm{~B}_{3}$ and $\mathrm{C}_{3}$ from top to bottom.

The minor gas sands of Titas gas field, i.e. $B_{1}, B_{2}, C_{1}, C_{2}$ and $C_{4}$ in the western flank and $B_{0}-E, B_{1}-E, B_{2}-E, C_{0}-E, C_{1}-E, C_{2}-E, C_{4}-E$ are of limited spatial extent. As far as the major gas sands of Titas gas fields are the main concern, the most significant gas sands are $\mathrm{A}_{2}$, $\mathrm{A}_{3}, \mathrm{~A}_{4}, \mathrm{~B}_{3}$ and $\mathrm{C}_{3}$. ' $\mathrm{A}_{2}$ ' sand is the thickest among all gas sands hence the most productive sands also. The $\mathrm{C}_{3}$ sands are thinnest of the five major sands. The sands show a more or less uniform thickness of $50 \mathrm{ft} \pm$ throughout the field, indicating a homogeneous energy condition when they were deposited. The gas reserve of Titas gas field was calculated in 2010 by RPS energy consultants to be $6.36 \mathrm{Tcf}$, with some more development work done. Cumulative production of the field till July 31, 2017 is 4383.102 billion cubic feet (bcf) gas which is $57.81 \%$ of the total recoverable reserve. Out of 27 wells, 24 wells are producing gas every day.

\section{Materials and Methods}

The investigation has been done to find out the reasons behind the gas seepage problem, the credible sources of seepage in Titas gas field. Various types of data were a prerequisite for this job and were collected from different sources. Titas well location was gathered from BAPEX and plotted on a map. Gamma ray log, resistivity log, sonic $\log$, density $\log$, neutron $\log$ and CBL/VDL log of Titas-10 well were assembled from BAPEX and evaluated for major gas sand reservoirs identification and for the assessment of cement bonding condition against all major gas sands in the well. Scrutinizing this cement bond log was very helpful in recognizing the potential sources of gas seepages. A reconnaissance was conducted in the seepage affected area in Brahmanbaria sadar Upzilla. A resistivity survey was directed in order to identify shallow subsurface fault which might be a potential conduit for surface seeping gas. Data were acquired from the survey using superstring R8 and analyzed for fault identification using AGI EarthImager 2D software. Seepage points in the locality from both ground and water body were inspected, photographed and the coordinates of these seepages were collected. These seepage points were plotted on a map to overview the surface distribution and analyzed to identify any kind of connection with Titas wells trajectories. Overall, almost all of data which could be beneficial to the research work were collected and analyzed during the period. 


\section{Results and Discussion}

Resistivity survey: The electrical resistivity surveys have been conducted using dipoledipole electrode configuration to investigate underground lithology, structure, layers, discontinuities and the main focus was on identifying traces of subsurface fault. The electrode spacing for each line is 8 meter and no roll-along surveys have been recorded, so the total distance coverage for the lines was $(83 \times 8)=664$ meter. Overall, three resistivity lines have been recorded in Titas-Meghna floodplain near Titas-06, 08, 09 and 10, where surface gas seepage is very prominent (Fig. 4). The resistivity lines are denoted by Line A, Line B, Line C, respectively. Lines $\mathrm{A}$ and $\mathrm{C}$ have been recorded along the major N-S trending anticlinal axis of Titas gas field while Line B has been taken across the axis where gas seepages are more prominent.

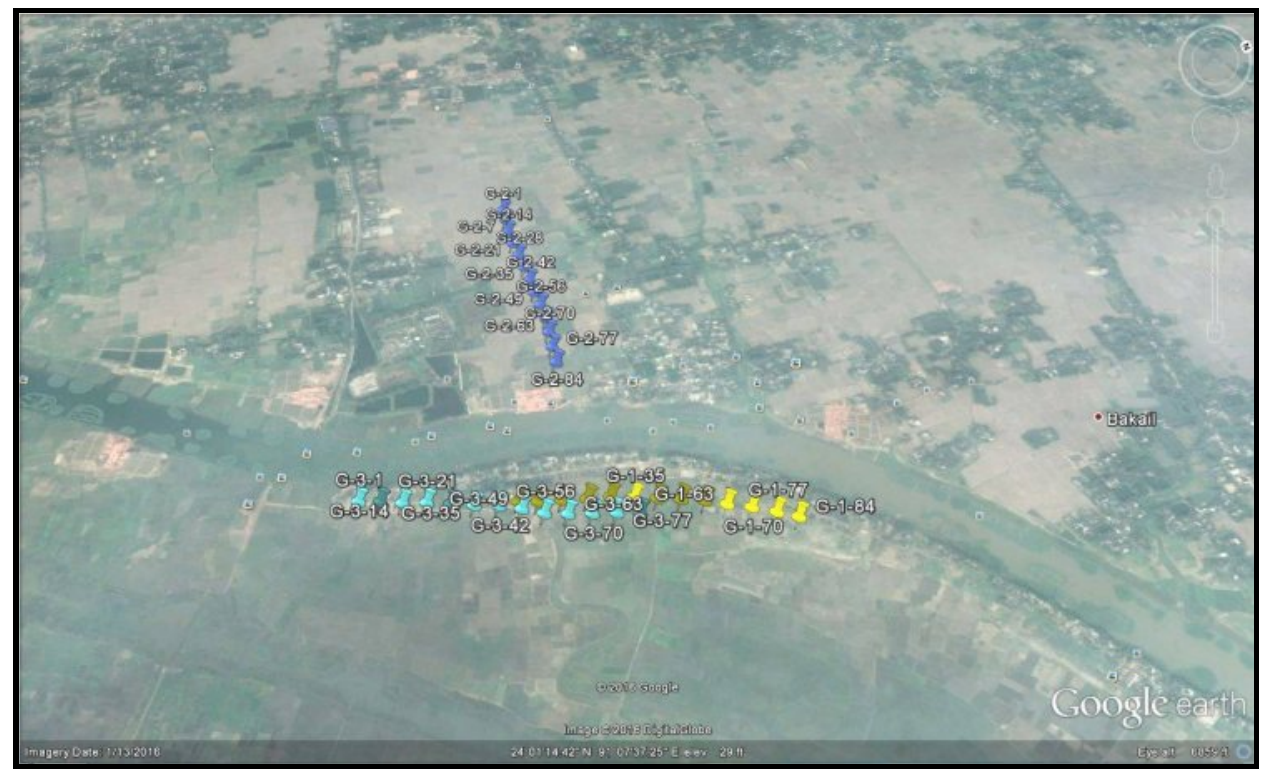

Fig. 4. Google image showing resistivity survey locations: Titas Line A (yellow color), Titas Line $\mathrm{B}$ (blue color) and Titas Line C (green color).

Line A is showing lower resistivity throughout the section though it is showing higher value in low electrode end than in high electrode end. The line is also showing high resistivity within 20 meters below the surface which is confined from the center point of the line to high electrode end (Fig. 5). This high resistivity layer indicates the lithology to be fine grained sand body while the surroundings are composed of thick shale layer. 
Line B is showing high resistivity layer continuous throughout the area within 50 meters below the surface. The resistivity value is even higher in high electrode end than in low electrode end. The high resistivity layer is indicated as fine-grained sand body of Titas floodplain. Below this, there is a low resistivity layer which continuous throughout the line (Fig. 6). This thin low resistivity layer has been detected as shale. There is another high-resistivity layer at the bottom of the section which is also continuous throughout the line which could be an indicator of shallow gas pocket.

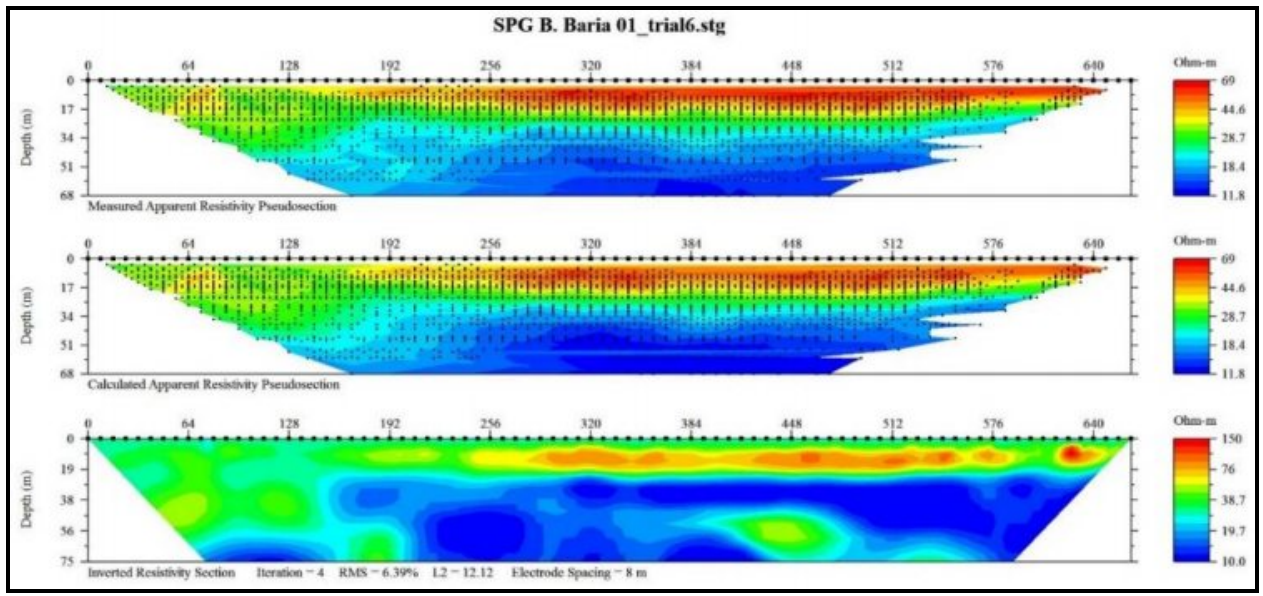

Fig. 5. Titas Line A resistivity section.

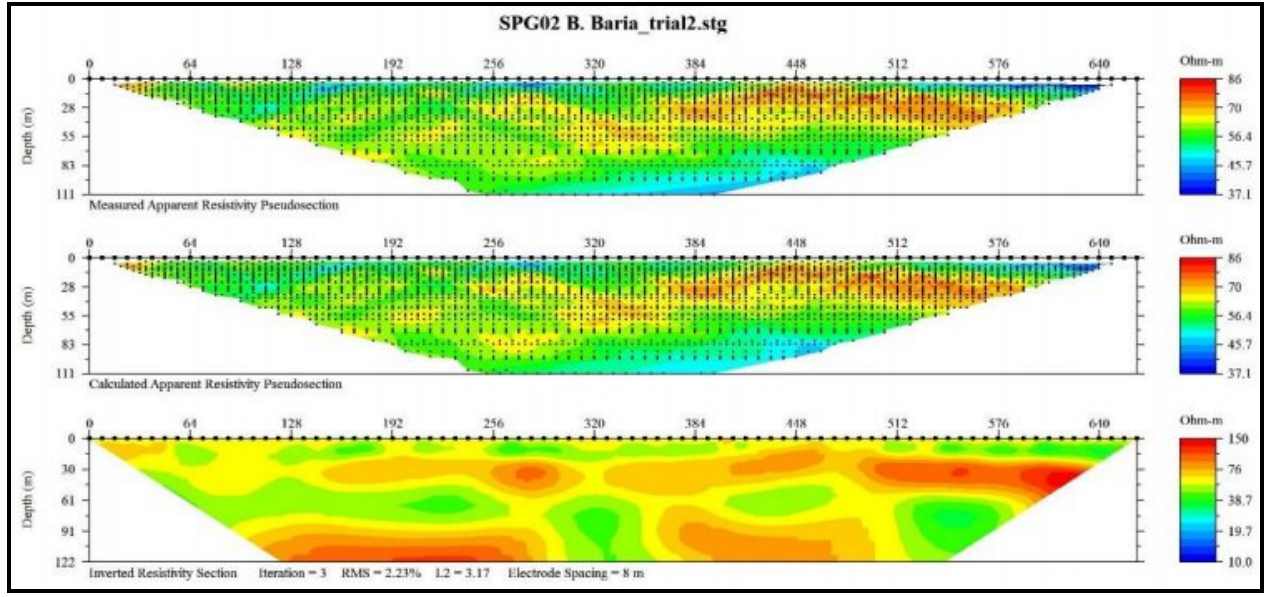

Fig. 6. Titas Line B resistivity section. 
Line $\mathrm{C}$ is showing very low resistivity at the bottom of the section which indicates a thick shale layer of floodplain deposit which is around 60 meters below the surface. The upper part is showing low to moderate resistivity continuously from low electrode end to high electrode end indicative of floodplain deposit. There is a small resistivity change from the surrounding low resistivity layers (Fig. 7). The high resistivity portion of the section could be just a sand body or it could be shallow gas pocket surrounded by shaly floodplain deposits. The data recorded are more or less continuous in the resistivity line and no abrupt change was observed. Therefore, the resistivity lines do not show any indication of faults.

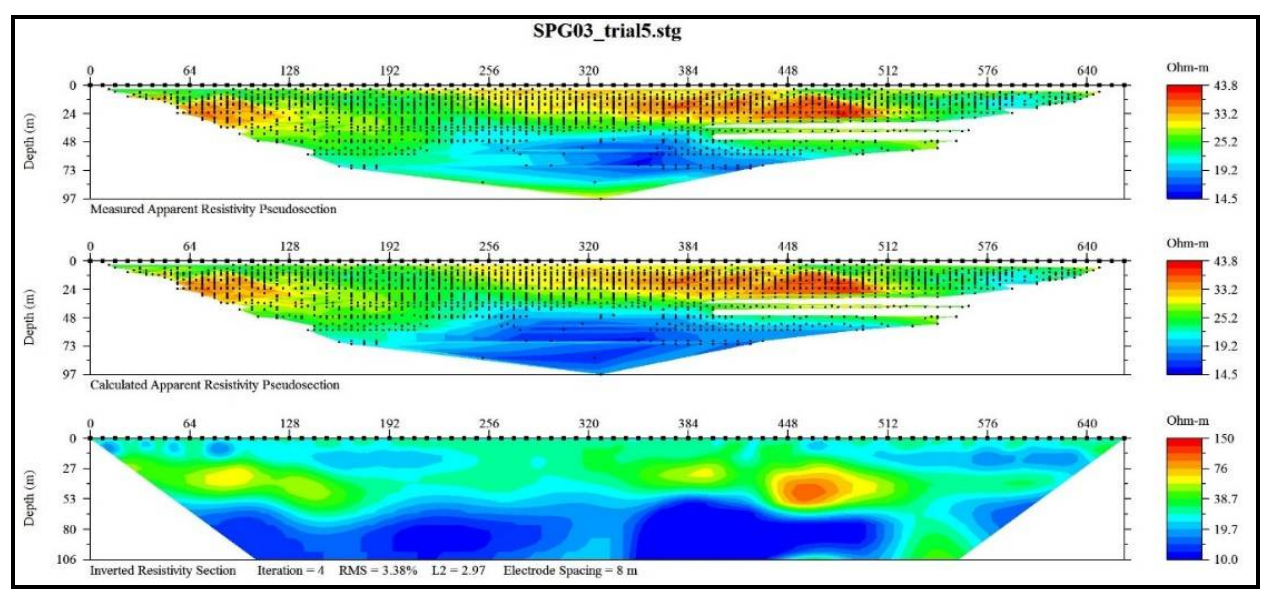

Fig. 7. Titas Line $\mathrm{C}$ resistivity section.

Wireline log analysis: Major reservoir sands ' $\mathrm{A}_{1}$ ', ' $\mathrm{A}_{2}$ ', ' $\mathrm{A}_{3}$ ', ' $\mathrm{A}_{4}$ ', ' $\mathrm{B}_{3}$ ' and ' $\mathrm{C}_{3}$ ' in Titas10 well has been identified using various wireline $\log$ i.e. gamma ray $\log$, resistivity $\log$, sonic log, neutron porosity log and density log. All gas sands were marked in terms of their depths and their thickness has been noted. Lithologies have been identified in terms of gamma ray log in Titas-10 well while shale layers give higher values of average 129 API units and gas bearing sands show lower gamma ray values ranging on an average from 94-111 API units for each gas sands.

Gas sands have been determined by comparing resistivity values where water-bearing sand has the lowest value (av. $5.42 \Omega-\mathrm{m}$ ) followed by shale (av. $9.63 \Omega-\mathrm{m}$ ). Sands containing gas showed the highest values in different intervals ranging from 20 to $34 \Omega$ $\mathrm{m}$ on an average for every gas sand. Lithologies have also been established by studying sonic log while shale shows highest interval transit time of av. $87 \mu \mathrm{s} / \mathrm{ft}$. and gas sands 
display slightly higher interval transit time (ranging from 76 to $87 \mu \mathrm{s} / \mathrm{ft}$.) than water bearing sand (avg. $69.8 \mu \mathrm{s} / \mathrm{ft}$.). Formations have been studied on the basis of neutron porosity log of Titas-10 well, which shows highest value in shale formation (av. 0.37) while gas bearing sand showed lower values (ranging from 0.19 to 0.24 ) than water bearing sand (av. 0.28). The density log values of gas bearing sands vary from 2.31 to 2.51. ' $\mathrm{A}_{1}$ ' sand in Titas-10 well has also been identified, and top and bottom of the sand has been demarcated studying neutron and density composite log.

Table 1. Top and bottom of major gas sands in Titas-10 well demarcated from gamma ray $\log$, resistivity log, sonic log, neutron porosity $\log$ and density $\log$.

\begin{tabular}{ccc}
\hline Gas sand & Top $(\mathrm{m})$ & Bottom $(\mathrm{m})$ \\
\hline ' $\mathrm{A}_{1}$ ' & 3157 & 3187 \\
'A $\mathrm{A}_{2}$ ' & 3199 & 3241 \\
' $\mathrm{A}_{3}$ ' & 3251 & 3287 \\
'A $\mathrm{A}_{4}$ ' & 3301 & 3337 \\
' $\mathrm{B}_{3}$ ' & 3486 & 3522 \\
' $\mathrm{C}_{3}$ ' & 3591 & 3610 \\
\hline
\end{tabular}

Low amplitude in CBL and strong formation signals in VDL indicates good cement bonding against the formation. High amplitude value in CBL, no formation signals in straight VDL and "V" type Chevron patterns at collar locations suggest the studied formation to be devoid of cement. Cement bond log of Titas-10 well has been studied and analyzed in order to infer the cement bond condition against targeted ' $\mathrm{A}_{1}$ ' gas sand. It is distinctly observed that cement bond $\log$ value of ' $\mathrm{A}_{1}$ ' gas sand of Titas-10 well ranges from $7 \mathrm{mV}$ to $85 \mathrm{mV}$ with an average of $44.14 \mathrm{mV}$, which indicates the cement bond condition in $3157-3180 \mathrm{~m}$ interval is very bad (Table 2). There is a $2-3 \mathrm{~m}$ interval with good to fair cement bonding (3163 - $3168 \mathrm{~m}$ ) in the top zone of ' $\mathrm{A}_{1}$ ' gas bearing sand, however the overall cement bond status against ' $\mathrm{A}_{1}$ ' sand is very poor.

Surface seepage distribution and extent: The areal extent of gas seepage distribution is around $7 \mathrm{sq}$. km. Seeping of gas has been seen in numerous locations as agricultural lands, ponds, tube wells and river. Gas is leaking through these points and escaping to the surface (Fig. 8). Locals started collecting the gas to use gas for household purpose and to run small industries soon after the gas seepages noticed. Noticeable seepage points have been studied and the GPS coordinates have been collected and plotted to create seepage distribution map. 


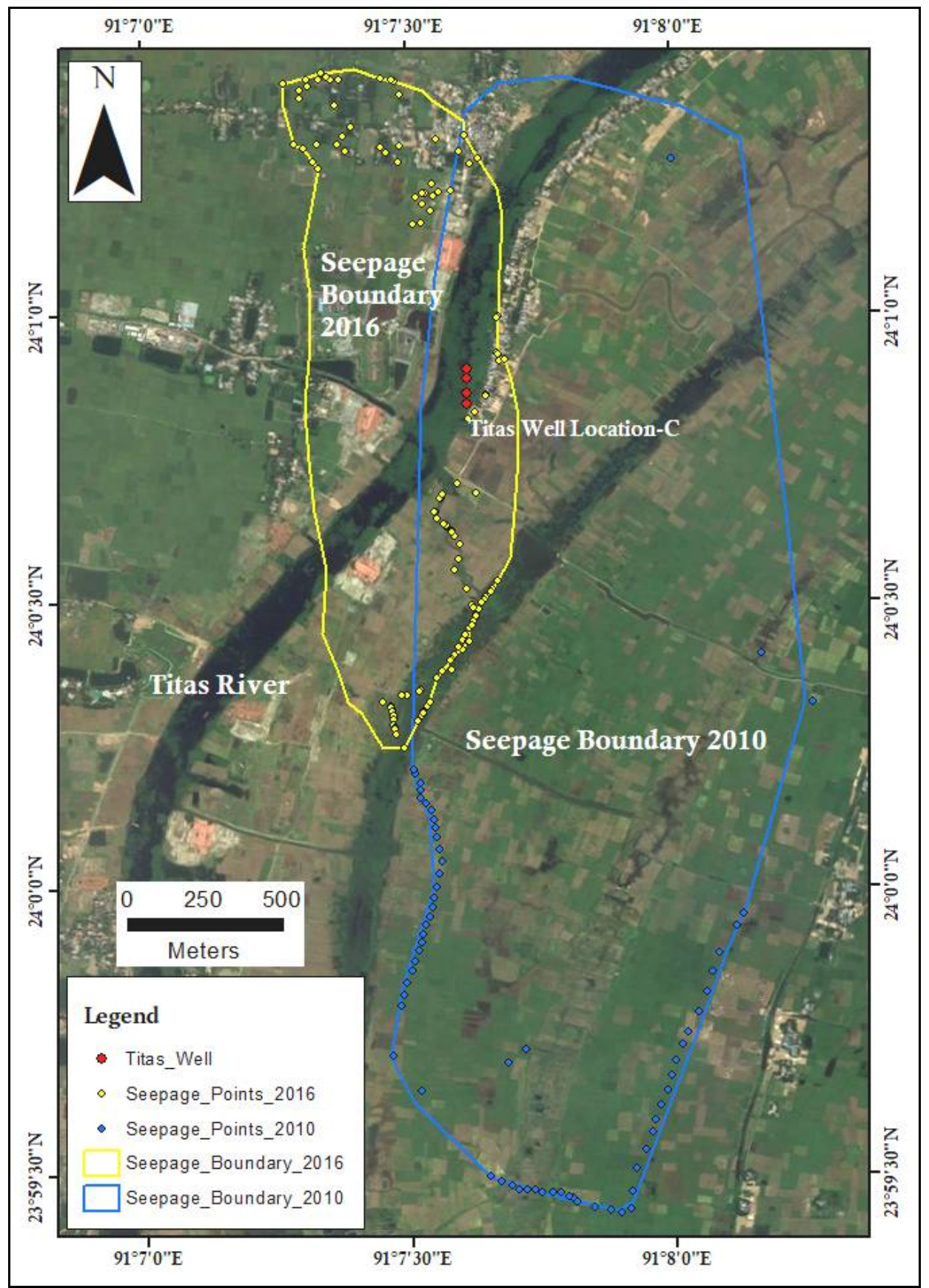

Fig. 8. Titas seepage distribution map over time. 
Seepages in relation to wells: Gas seepages distribution is more or less same over time. These seepages are observed around the central area of Titas Well Location $\mathrm{C}$ which includes Titas Well nos. 6, 8, 9 and 10 (Fig. 9). Changes in seepage distribution over time, remained more or less close to Titas Well Location $\mathrm{C}$ than others.

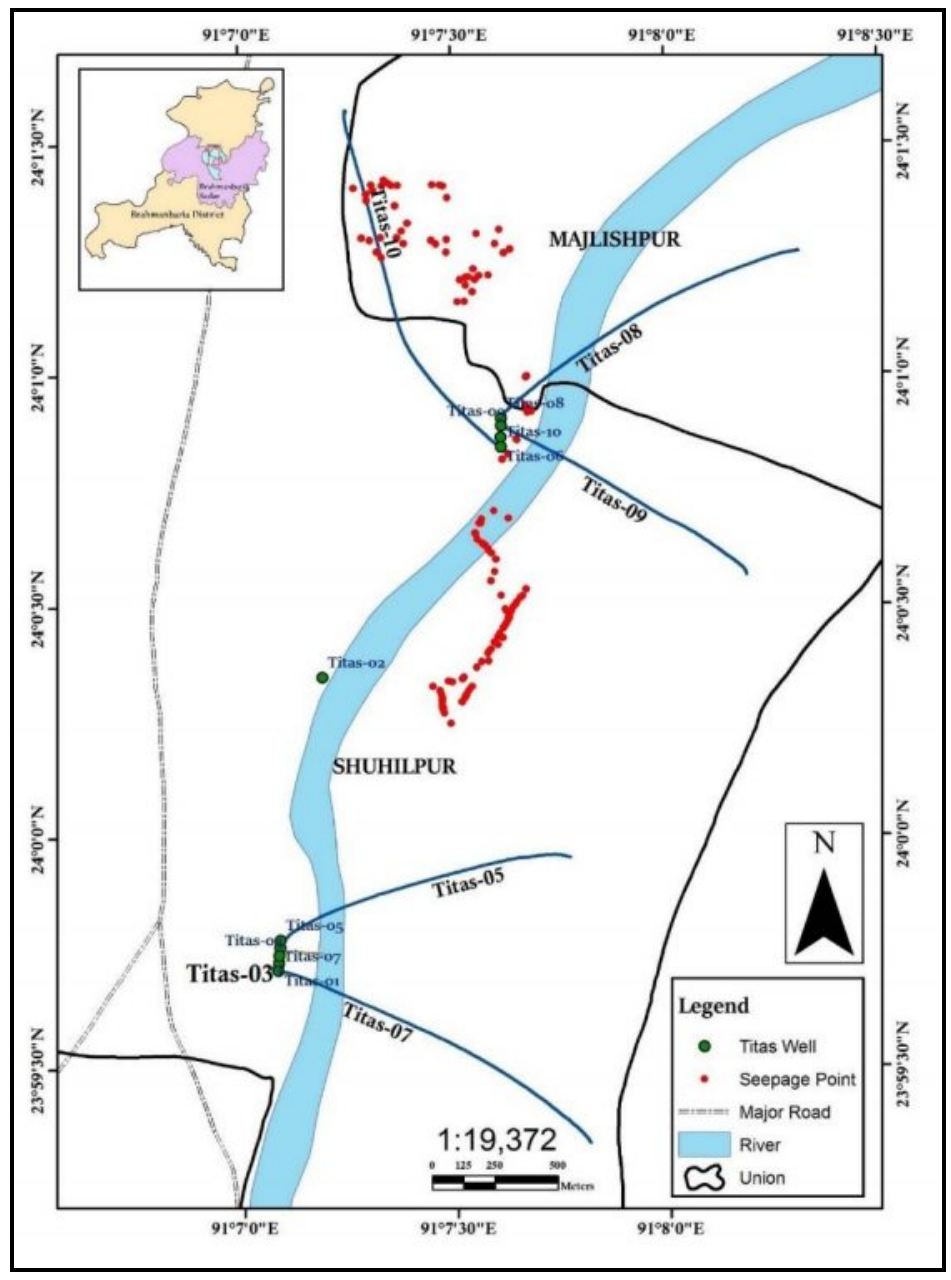

Fig. 9. Titas gas seepages in relation to wells.

Some of the Titas wells are deviated well, their subsurface locations are plotted on the map with surface seepage distribution. Subsurface location of Titas well no. 8, Titas Well no. 9 and Titas Well no. 10 overlaps with surface seepage distribution pattern, whereas the location of vertical Titas well no. 3 is almost $3 \mathrm{~km}$ away from the current seepage 
points, which has been killed with an idea of being the contributor of Titas gas seepage. This map indicates the seeping gas from the main reservoir could be migrated where fault line may work as a conduit from direct below subsurface where Titas Well nos. 8, 9 and 10 are located and Titas well no. 3 might not be the faulty well at all.

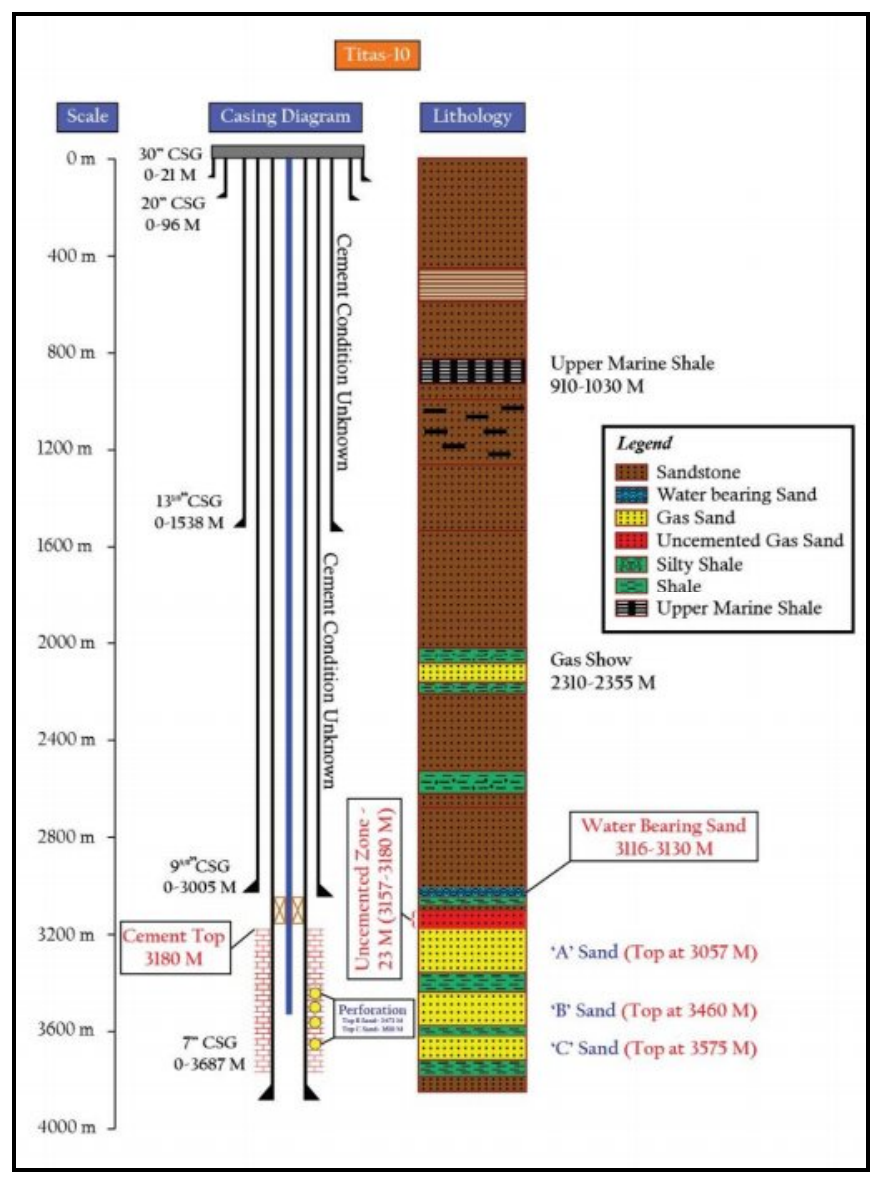

Fig. 10. Schematic diagram of Titas Well No. 10 showing casing and cementing against rock type.

Sources of gas seepage: BGFCL first noticed gas seepages in the southeastern part of Titas gas field beside Titas river in November, 2006. They have made a committee submitted a report to Petrobangla in February, 2007. The surface seepage distribution map indicated that any of the wells located at Titas Well Location C could be responsible for this unprecedented gas seepage. The expert committee closely observed and studied well history, production data, drilling data and geological data and interpreted all log data 
available for the above-mentioned wells located at location C. Finally, the committee theorized that the source of gas seepage could be from the well nos. 8, 9 or 10 . They recommended to conduct circulating cement squeeze job and to run necessary logs specially CBL-VDL in well nos. 8, 9 and 10 by appointing expert well control specialist.

Comments on seepage source: Titas-10 well has drawn all the attractions as all newest and still existing seepages coincide along the Titas-10 well trajectory. Cement bond analysis illustrate that top of cement against major gas sands is at $3180 \mathrm{~m}$ MD while top of 'A' gas sand resides at $3157 \mathrm{~m}$ MD. This (3157 m MD-3180 m MD) uncemented zone is most possibly responsible behind gas seepages in Titas gas field. There is also a water bearing sand at 3116-3130 m MD. There is a possibility of cross-flow of gas and water between water bearing sand and gas sand ' $\mathrm{A}$ ' which might eventually cause gas to leak to the surface. Moreover, 'A' sand in Titas-10 well was found dry which clearly bolster the assumption of gas leaking from this well, while log signatures in the sand directed that there was enough gas to flow into the well. Accordingly, prior to these facts it can be distinctly claimed that the top of ' $\mathrm{A}$ ' gas sand $\left(\mathrm{A}_{1}\right)$ in Titas-10 well is the sole contributor of Titas gas seepages (Fig. 10).

Table 2. Detail well information including cement bond condition in Titas gas field.

\begin{tabular}{|c|c|c|c|c|c|}
\hline $\begin{array}{l}\text { Well } \\
\text { No. }\end{array}$ & Year & $\begin{array}{l}\text { Well } \\
\text { type }\end{array}$ & $\begin{array}{c}\text { Drilled } \\
\text { depth }\end{array}$ & $\begin{array}{l}\text { 'A' sand } \\
\text { encounter }\end{array}$ & $\begin{array}{l}\text { 'B' sand } \\
\text { encounter }\end{array}$ \\
\hline Titas-03 & 1969 & Vertical & $2839 \mathrm{~m}$ & $2617 \mathrm{~m}$ & - \\
\hline Titas-08 & 1985 & Directional & $3583 \mathrm{~m} \mathrm{MD}$ & $3038 \mathrm{~m} \mathrm{MD}$ & $3292 \mathrm{~m} \mathrm{MD}$ \\
\hline Titas-09 & 1987 & Directional & $3625 \mathrm{~m} \mathrm{MD}$ & $3057 \mathrm{~m} \mathrm{MD}$ & $3310 \mathrm{~m} \mathrm{MD}$ \\
\hline Titas-10 & 1988 & Directional & $3699 \mathrm{~m} \mathrm{MD}$ & $3157 \mathrm{~m} \mathrm{MD}$ & $3460 \mathrm{~m} \mathrm{MD}$ \\
\hline \multicolumn{6}{|c|}{ right side of the table } \\
\hline \multicolumn{2}{|c|}{ 'C' sand encounter } & Top of cement & \multicolumn{3}{|c|}{ Cement bond condition } \\
\hline \multicolumn{2}{|c|}{-} & $1678 \mathrm{~m}$ & \multicolumn{3}{|c|}{ Quite good against 'A', 'B' and 'C' sand } \\
\hline \multicolumn{2}{|c|}{$3438 \mathrm{~m} \mathrm{MD}$} & $2800 \mathrm{~m} \mathrm{MD}$ & \multicolumn{3}{|c|}{ Quite good against 'A', 'B' and 'C' sand } \\
\hline \multicolumn{2}{|c|}{$3462 \mathrm{~m} \mathrm{MD}$} & $3033 \mathrm{~m} \mathrm{MD}$ & \multicolumn{3}{|c|}{ Good against ' $A$ ', ' $B$ ' and ' $C$ ' sand } \\
\hline \multicolumn{2}{|c|}{$3575 \mathrm{~m} \mathrm{MD}$} & $3180 \mathrm{~m} \mathrm{MD}$ & \multicolumn{3}{|c|}{ Top of ' $A$ ' sand is unprotected } \\
\hline
\end{tabular}

\section{Conclusion}

Titas gas seepages have been observed in the proximity of Titas well location $\mathrm{C}$, from where Titas-6, 8, 9 and 10 have been drilled and still producing gas. Surface seepage distribution has been paralleled with well paths of nearby wells of location-C and found to be coincided with Titas-9 and 10 well paths. No traces of fault or fracture was recognized in any of the three resistivity lines acquired.The abandoned Titas- 3 well has 
been cleared out of discussion as the well location is almost $3 \mathrm{~km}$ far from seepage affected area while no indication of fault in resistivity survey supported this action.

Numerous remaining seepages in the affected area suggest the decision of killing Titas-3 well was wrong. Despite of based in the seepage disturbed area, Titas- 8 and 9 wells have been cleared out of suspicion as cement bonding against major reservoir sands of these two wells are good to excellent.Titas-10 well has been studied with great care as most of recent and existing seepages lie along the well trajectory of this well. Resistivity, sonic, neutron and density $\log$ signatures of Titas-10 well evidently shows that ' $\mathrm{A}_{1}$ ' sand is a good gas bearing sand and gas has been producing for many years in other Titas wells from this sand. The structurally high Titas-10 well cannot just be expelled by producing in some other wells. Therefore, gas seeping from this sand must have to be the only explanation behind the dry ' $\mathrm{A}_{1}$ ' sand. Log signatures show that ' $\mathrm{A}_{1}$ ' and ' $\mathrm{A}_{2}$ ' gas sands are separated only by a 6-meter-thick shale in Titas- 10 well. It has also been inferred that the quality of this shale is not quite good. There is a slight possibility of gas migration from ' $\mathrm{A}_{2}$ ' sand to ' $\mathrm{A}_{1}$ ' sand by breaching this shale layer. No drill stem test has been conducted in ' $\mathrm{A}_{2}$ ' sand in Titas-10 well so far, therefore, it cannot be sure whether gas is also leaking from ' $\mathrm{A}_{2}$ ' sand or not. No one can say that all the gas leaking from the reservoir is seeping to the surface. A certain portion of gas might have accumulated in small localized traps. It will be extremely risky to drill wells in this field if there is the possibility of presence of shallow gas in unknown horizons. This gas might also affect the quality of the future seismic survey.

\section{Acknowledgements}

The authors would like to convey their tribute to Ministry of Science and Technology on this occasion for providing them with National Science and Technology (NST) fellowship which covered all our expenses during the research work. Authors are extremely obliged to Mr. Mizanur Rahman, Deputy General Manager, Geological Division, and BAPEX for his valuable time and suggestions during the completion of study.

\section{References}

Acharyya, S.K., N.D. Mitra and D.R. Nandy 1986. Regional geology and tectonic setting of northeast India and adjoining region. Memoirs of the Geological Survey of India, 119: 6-12.

Alam, M.M., J.R. Alam, M.L.R. Curray and M.R. Gani Chowdhury. 2003. An overview of the sedimentary geology of the Bengal basin in relation to the regional tectonic framework and basin-fill history. Sedimentary Geology 155(3-4), 179-208. 
Geological and geophysical observations to determine the gas seepage

Banu, S. and D. Hossain, D 2000. A Seismo-Geological Interpretation and Hydrocarbon Prospects of Chhatak Structure, Surma Basin, Bangladesh, Bangladesh Geoscience Journal, Volume 6, ISSN:1028-6845, 17-25.

Biswas,S. 2005. Tectonic geomorphology along the Dauki Fault and 3D visualization of the Sylhet Trough (Bangladesh), In: Department of Geological Sciences, University of Vienna, Vienna. 116.

Coleman, J. M. 1969. Brahmaputra River: Channel processes and sedimentation. Sedimentary Geology 3(2-3): 129-239.

Estes, J. E., R.E. Crippen and J.L. Star 1985. Natural oil seep detection in the Santa Barbara Channel, California, with Shuttle Imaging Radar, Geology 13: 282-284.

Etiope, G. and P. Ciccioli 2009. Earth's degassing: a missing ethane and propane source. Science, 323(5913): 478-478.

Evans, P. 1964. The Tectonic framework of Assam, Journal of Geological Society of India. 5: 8096.

Farhaduzzaman, M., M.A. Islam, W.H. Abdullah and M.S. Islam. 2015. Petrography and diagenesis of the Tertiary Surma Group reservoir sandstones, Bengal Basin, Bangladesh. Universal Journal of Geoscience 3(3): 103-117.

Fischer, P.J. and A.J. Stevenson. 1973. Natural Hydrocarbon Seeps along the Northern Shelf of the Santa Barbara Basin, in Santa Barbara Channel Revisited, AAPG Trip 3, Annual Meeting AAPG, SEPM, SEG.

Hiller, K.and M. Elahi. 1984. Structural development and hydrocarbon entrapment in the Surma basin/Bangladesh (northwest Indo-Burman fold belt).

Hunt, M.J. 1979. Petroleum geochemistry and geology. WH Freeman and company.

Huq, M.M. 2009. Gas Seepages in Titas. Energy \& Power, Vol. 6, Issue 24, June 1-15.

Imam, B. 2013. Energy Resources of Bangladesh. Second Edition, University Grants Commission Publication No.151, ISBN 984-809-020-1, Bangladesh, 2013, p. 324.

Johnson, S.Y. and A.N.M. Alam 1991. Sedimentation and tectonics of the Sylhet trough, Bangladesh. Geological Society of America Bulletin, 103(11): 1513-1527.

Khan,S.H., S. Biswas, S. Singh and P. Pati 2006. Chronology of Dihing Formation and Recent Upliftment Rate Along the Dauki Fault, NE Bangladesh, Bangladesh Geoscience Journal, 12: $1-10$.

Kolpack, R.L. 1977. Relationship of migration of natural seep material to oceanography of Santa Barbara Channel, in California Offshore Gas, Oil, and Tar Seeps, California State Lands Commission, p. 226-255.

Leitz, J.K. and J. Kabir 1982. Prospects and constraints of oil exploration in Bangladesh. Fourth Offshore Southeast Asia Conference, Singapore, pp. 1-6.

Link, W.K. 1952. "Significance of Oil and Gas Seeps in World Oil Exploration", AAPG Bull. 6(8): $1505-1540$.

Matin, M. A., M. Fariduddin, A.I. Konokov and M.M.T. Husain 1984. Oil Prospects of Titas Structure. Bangladesh Journal of Geology 3: 11-18.

Miah, M. I. and M.F. Howladar 2014. Hydrocarbon Bearing Zone Detection and Water Saturation Estimation: A Case Study of Bokabil Formation, North Eastern Part of Bengal Basin. In 9th Int'l Forum on Strategic Technology (IFOST). pp. 21-23.

Sibson, R.H. 1996. Structural Permeability of fluid-driven fault-fracture meshes. Journal of Structural Geology. 18(8): 1031-1042.

Tinkle, A.R., Antoine, J.W. and Kuzela, R. 1973. Detecting natural gas seeps at sea. Ocean Industry. 8: 139-142. 